\title{
Miejsca Leśmiana - dzisiaj (o najnowszej recepcji krytycznoliterackiej)
}

Wykaz literatury przedmiotu w książce Miejsca Leśmiana. Studium topiki krytycznoliterackiej ${ }^{1}$ kończy się na roku 2006, właściwy materiał badawczy stanowiły jednak świadectwa recepcji z lat 1902-2000. Pisząc dzisiaj postscriptum do Miejsc Leśmiana, zaczynam tam, gdzie zakończyłam stuletnią historię krytycznoliterackiej recepcji Leśmiana, czyli około roku 2000. To data całkowicie umowna - nie stanowi żadnej cezury ani w dziejach odbioru krytycznoliterackiego (który jest głównym przedmiotem moich zainteresowań), ani też w równoległych dziejach naukowej leśmianologii (którą uwzględniam w tym zakresie, w jakim realizuje funkcje właściwe krytyce). Cezura właściwa przypada na pierwsze lata ostatniej dekady XX wieku: wtedy zaczął się okres, który w książce określiłam jako „jeszcze jeden powrót do Leśmiana". Przypomnę, że Powrót do Leśmiana to tytuł szkicu Stanisława Lema opublikowanego w „Tygodniku Powszechnym” w 1996 roku i że taki sam tytuł nosił tekst Wiesława Pawła Szymańskiego zamieszczony w tym samym czasopiśmie w roku $1962^{3}$ - wystąpienia te nie tyle zainicjowały dwa kolejne „powroty do Leśmiana”, co były wyrazem świadomości, że "powrót" właśnie się dokonuje.

Od początku lat dziewięćdziesiątych XX wieku nastąpiło przyspieszenie recepcji i po roku 2000 tendencja ta się utrzymała. Tradycyjnie liczba świadectw odbioru wzrastała w latach jubileuszowych: 2007 i 2017. Nowością

* Uniwersytet Wrocławski, Wydział Filologiczny, Instytut Filologii Polskiej, Zakład Teorii Literatury, e-mail: malgorzata.gorczynska@uwr.edu.pl.

1 M. Gorczyńska, Miejsca Leśmiana. Topika recepcji krytycznoliterackiej, Kraków 2011.

2 S. Lem, Powrót do Leśmiana, „Tygodnik Powszechny” 1996, nr 46.

3 W.[P.] Szymański, Powrót do Leśmiana, "Tygodnik Powszechny” 1962, nr 45. 
było natomiast zagęszczenie rytmu rocznicowego: w roku 2012 upłynęło sto lat od publikacji pierwszej książki poetyckiej Leśmiana i z tej okazji na Uniwersytecie Jagiellońskim odbyła się konferencja naukowa pt. Stulecie "Sadu rozstajnego". Można to zdarzenie potraktować jako wyraz potrzeby, by leśmianologiczny dialog przebiegał bardziej regularnie - badacze i krytycy nie czekają już na zwyczajowe okazje, lecz kreują własne.

Punktem odniesienia dla przyspieszającego procesu jest okres poprzedzający najnowszy „powrót do Leśmiana” - ćwierćwiecze stabilizacji. W leśmianologii zyskał wówczas przewagę dyskurs akademicki, wypowiedzi krytycznoliterackie zeszły na dalszy plan (tak jest zresztą do dzisiaj, jeśli wziąć pod uwagę procentowy udział tekstów krytycznych - w liczbach bezwzględnych odnotować ich jednak należy znacząco więcej niż w dekadach poprzednich). Charakterystyczna dla tego wcześniejszego etapu recepcji może być uwaga Bohdana Zadury w przedmowie do Poezji Leśmiana z 1982 roku:

Nie jest [...] Bolesław Leśmian poetą nieznanym ani zapoznanym. Wiadomo o nim jeśli nie wszystko, to wystarczająco dużo, bym nie miał złudzeń, iż potrafię ową wiedzę w najskromniejszy bodaj sposób uzupełnić4

Nowy „powrót” stał się możliwy dzięki przekonaniu, że Leśmian jednak nie został do końca poznany. Przekonanie to zyskało zaś wsparcie w publikacjach Leśmianowskich ineditów. Rozpoczęta w połowie lat osiemdziesiątych XX wieku akcja wydawnicza Rochelle Stone (Skrzypek opętany, Pierrot $i$ Kolombina, 1985; Życie - snem, 1987), Wacława Lewandowskiego (Klechdy polskie, 1999), Jacka Trznadla (Zdziczenie obyczajów pośmiertnych, 1998) oraz Dariusza Pachockiego (Satyr i Nimfa, Baśń o złotym grzebyku, z Arturem Truszkowskim, 2011; Zdziczenie obyczajów pośmiertnych, 2014; Skrzypek opętany, 2016) uświadomiła leśmianologom, że są jeszcze $\mathrm{w}$ twórczości poety obszary niezbadane lub przebadane niedostatecznie oraz że twórczość ta wciąż nie jest dostępna w całości i w pełnej, niezafałszowanej postaci (ani Poezje zebrane w opracowaniu Aleksandra Madydy, 1993, ani przygotowane przez Trznadla Dzieła wszystkie, t. 1-4, 2010-2013, nie spełniają wszystkich wymogów stawianych edycjom krytycznym). Pachocki swoją rzeczową relację o perypetiach edytorskich rękopisów przechowywanych obecnie w Ransom Center w Austin zakończył fantazją na temat tajemniczej walizki z manuskryptami Leśmiana, złożonej w czasie wojny w piwnicy domu przy ul. Rakowieckiej: „Przetrwała ona zarówno bombowe naloty, jak i powstańczą zawieruchę. Czeka"5. Obraz rękopisów czekających na odnalezienie i publikację można transponować na całą twórczość Leśmiana: ona również zdaje się oczekiwać na swoich edytorów i interpretatorów.

4 B. Zadura, „Trudno dać imię temu, co w dalekość ptynie...", [w:] B. Leśmian, Poezje, wybrał i wstępem opatrzył B. Zadura, Lublin 1982, s. 5.

5 D. Pachocki, Zagadnienia i zagadki edytorskie w rękopisach Bolestawa Leśmiana, „Tematy i Konteksty" 2012, nr 2, s. 124 . O „brulionach z Rakowieckiej” pisał też Jarosław Marek Rymkiewicz, zob. tegoż, Leśmian. Encyklopedia, Warszawa 2001, s. 31-34. 
Tak w każdym razie widzą to leśmianolodzy, jak można sądzić z powtarzających się narzekań na niedostateczne zainteresowanie twórczością Leśmiana. „Od dłuższego czasu nie ma już ani jednej placówki badawczej uniwersyteckiej bądź akademickiej, w kraju i na świecie, specjalizującej się w tym zakresie"6 - pisał Eugeniusz Czaplejewicz we wstępie do zbioru Poetyki Leśmiana (2002). Pięć lat później Michał Paweł Markowski stwierdził: „Studia nad Leśmianem nie są, jak na poetę tej miary, ani zbyt obfite, ani nazbyt intrygujące"7. W 2012 roku opinię tę powtórzyli Bogusław Grodzki i Dariusz Trześniowski: „Mimo że Bolesław Leśmian jest uważany za jednego z najwybitniejszych poetów polskich dwudziestego wieku, istnieje stosunkowo niewiele książek poświęconych jego twórczości" ${ }^{\prime 8}$. Trudno powiedzieć, ile książek leśmianolodzy uznaliby za liczbę satysfakcjonującą, zważywszy na fakt, że tylko w latach 2000-2011 ukazało się osiem monografii naukowych", trzy książki zbiorowe ${ }^{10}$, trzy biografie ${ }^{11}$, tom wspomnień ${ }^{12}$, a także sylwiczna Encyklopedia Jarosława Marka Rymkiewicza. W ciągu następnych pięciu lat czyli do momentu, gdy piszę te słowa - przybyły kolejne pozycje książkowe: sześć monografii ${ }^{13}$, książka zbiorowa ${ }^{14}$, antologia wierszy uzupełniona zbiorem szkiców siedmiorga autorów ${ }^{15}$ oraz katalog towarzyszący rocznicowej

6 E. Czaplejewicz, Słowo wstępne, [w:] Poetyki Leśmiana. Leśmian i inni, pod red. E. Czaplejewicza i W. Sadowskiego, Warszawa 2002, s. 5.

7 M.P. Markowski, Polska literatura nowoczesna. Leśmian, Schulz, Witkacy, Kraków 2007, s. 157.

8 Leśmian nowoczesny i ponowoczesny, pod red. B. Grodzkiego i D. Trześniowskiego, Radom 2012, s. 5.

9 J. Zięba, Bolesława Leśmiana światopogląd nowoczesny. O eseistyce poety, Kraków 2000; A. Sobieska, Twórczość Bolesława Leśmiana w kręgu filozoficznej myśli symbolizmu rosyjskiego, Kraków 2005; E. Boniecki, Archaiczny świat Bolesława Leśmiana. Studium historycznoliterackie, Gdańsk 2008; B. Stelmaszczyk, Istnieć w dwoistym świecie... Model człowieka i obrazy Boga w poezji Bolesława Leśmiana, Łódź 2009; M. Nawrocki, Wariacje istnieniowe. O ontologii poetyckiej Bolesława Leśmiana, Tarnów 2009; W. Cockiewicz, Metaforyka Leśmiana (analiza lingwistyczna), Kraków 2011; M. Gorczyńska, dz. cyt.

10 Oprócz przywołanej wcześniej książki Poetyki Leśmiana... są to także: Poezje Bolesława Leśmiana. Interpretacje, pod red. B. Stelmaszczyk i T. Cieślaka, Kraków 2000; Twórczość Bolesława Leśmiana. Studia i szkice, pod red. T. Cieślaka i B. Stelmaszczyk, Kraków 2000.

11 P. Łopuszański, Leśmian, Wrocław 2000; tenże, Zofia i Bolesław Leśmianowie, Kraków 2005; tenże, Bolesław Leśmian. Marzyciel nad przepaścią, Warszawa 2006.

12 Leśmian, Leśmian... Wspomnienia o Bolesławie Leśmianie, zebrane przez A.W. Kulika, Gdańsk 2008.

13 M. Kaźmierczak, Przekład w kręgu intertekstualności. Na materiale tłumaczeń poezji Bolesława Leśmiana, Lublin 2012; B. Grodzki, Leśmianowska baśń nowoczesna. O „Przygodach Sindbada Żeglarza" Bolesława Leśmiana, Lublin 2012; J. Wawryk, Wokót Leśmianowskich baśni dla dzieci, Wrocław 2013; P. Szwed, Oddaleniec. Poezja Bolesława Leśmiana wobec romantyzmu polskiego, Katowice 2014; K. Dobrowolska, Budowniczy złotych mostów. Leśmian i retoryczna krytyka metafor, Warszawa 2014; $\dot{Z}$. Nalewajk-Turecka, Leśmian międzynarodowy - relacje kontekstowe. Studia komparatystyczne, Kraków 2015

14 Stulecie "Sadu rozstajnego", pod red. U.M. Pilch i M. Stali, Kraków 2014.

15 B. Leśmian, "Lecz nie było już świata...". Miłość i śmierć. Wiersze, całość ułożył, fotografie wykonał i słowem wstępnym opatrzył A. Nowakowski, Kraków 2017. 
wystawie $^{16}$. Listy nie można uznać za kompletną (nie obejmuje np. prac, których Leśmian nie jest jedynym bohaterem, choć pojawia się w tytule), a przecież same tylko wymienione tu pozycje przekraczają liczebnie sumę wszystkich książek o poecie, które napisano w całym wieku XX.

Liczby nie wydają się jednak istotne: narzekanie na stan recepcji jest leśmianologicznym rytuałem i wynika z perswazyjnego ukierunkowania wypowiedzi (w metarefleksji zorientowanej poznawczo obraz przedstawia się zgoła odmiennie: komentatorzy zgodnie mówią o „lawinowym” przyroście prac o Leśmianie ${ }^{17}$ ). Przestrzeganie tego rytuału pozwala zachować tożsamość przedmiotu - bycie niedocenionym to wszak ważny składnik literackiej persony Leśmiana. Nie doceniali poety współcześni (nad tym ubolewano jeszcze za jego życia), nie mają dla niego wystarczającego uznania także późniejsze pokolenia krytyków i badaczy (jak można sądzić z obecnych narzekań). Niedocenienie jest więc dla leśmianologów zjawiskiem po części aktualnym, choć na ogół to recepcja „za życia” przedstawiana jest - nie bez słuszności, bo współczesne opinie na temat poety były najbardziej zróżnicowane - w najczarniejszych barwach. W narracji o późniejszych dziejach odbioru te zdarzenia, o których piszący chce pamiętać, są przedstawiane jako wyjątkowe i opatrywane rozmaitymi „co prawda” czy "nie licząc” (w zbiorowej świadomości leśmianologii najmocniej osadziły się wystąpienia Artura Sandauera, pamiętany jest też - to po części magia zagranicznego nazwiska - Paul Coates); o reszcie się nie wspomina. Dzięki tej wybiórczej pamięci „powrót do Leśmiana” zdarza się zawsze po raz pierwszy. Czaplejewicz, który pamiętał o okresie od lat sześćdziesiątych do połowy osiemdziesiątych XX wieku, gdy prac o poecie „przybywało lawinowo [sic!] zarówno w kraju, jak i za granicą", mimo wszystko uznał, że „leśmianologię dotknął los Leśmianowskiej Dziewczyny, co «spoczęła niezjawiona»"18. "Powrót” (również Czaplejewicz używa tego określenia) jest zatem sprawą przyszłości, inicjowaną już teraz przez badacza i jego współpracowników. Nowość „powrotu” wynika też z jakościowo-ilościowego stanu recepcji w okresie bezpośrednio poprzedzającym moment teraźniejszy - Czaplejewicz nie wahał się określić tej sytuacji mianem „wielce niekorzystnej”, a nawet „zatrważającej”19.

Krytyk lub badacz ogłaszający „powrót” sytuuje się w opozycji do odbiorców „wcześniejszych”, zwłaszcza profesjonalnych, i chętnie przedstawia się jako rzecznik czytelników („garstki” lub „rzeszy”, ale zawsze „wiernych”);

16 „Wiecznie siebie nowego głodnym, jak żuraw z szyją w przyszłość wyciąnięta” - Bolesław Leśmian 1877-1937, red. A. Kluba, Warszawa 2017.

17 A. Czabanowska-Wróbel, Dyskrecja, „Teksty Drugie” 2002, nr 1/2, s. 190; P. Polaszek, Poezja Bolesława Leśmiana w refleksji naukowej 2011-2015, [w:] Młoda Polska w najnowszych badaniach, pod red. E. Jakiela i T. Linknera, Gdańsk 2016, s. 119; we wcześniejszym sprawozdaniu Polaszka z recepcji naukowej Leśmiana pojawia się określenie „wysyp”, tenże, Recepcja poezji Bolesława Leśmiana w pierwszym dziesięcioleciu XXI wieku. Rekonesans, [w:] Literatura na progu XXI wieku, pod red. J. Chłosty-Zielonki i Z. Chojnowskiego, Olsztyn 2014, s. 43.

18 E. Czaplejewicz, dz. cyt., s. 5.

19 Tamże. 
w innym wariancie tej postawy akcentuje swoją przynależność do świata literatury (znów: w kontrze do zawodowych „znawców”). "Jestem w końcu pisarzem [...]"20 - to pierwsze słowa Powrotu do Leśmiana Lema. Dziwiąc się, że poeta w okresie międzywojennym „nie cieszył się [...] w ogóle należną sławą", powołał się on na wyższy autorytet pisarski: „I Szymborska w «Tygodniku Powszechnym» to zauważyła; dla niej także Leśmian jest największą naszą poetycką armatą"21 (pisał to półtora miesiąca po przyznaniu poetce Literackiej Nagrody Nobla). Lem kilkakrotnie podkreślił osobisty aspekt wysokiej oceny: ,jeszcze od czasów gimnazjalnych” Leśmian był jego „najukochańszym poetą" ${ }^{22}$. Autobiograficzne wzmianki o wczesnych kontaktach czytelniczych z poezją autora Łąki (najczęściej chodzi o ten właśnie zbiór) to również stały motyw leśmianologii. Przede wszystkim wspierają one sąd oceniający. Młodzieńcze zauroczenie jawi się jako autentyczne, szczere, zatem też bardziej wiarygodne. Gdzieś w tle pobrzmiewa wszakże nuta przechwałki, licytowania się na pierwszeństwo (istotne w kontekście absolutnej nowości „powrotu”).

Jacek Gutorow we wstępie do autorskiego wyboru wierszy Leśmiana Z tamtej strony ciszy rozpoznał ten autobiograficzny motyw jako mało oryginalny - a mimo to posłużył się nim, budując dość obszerną narrację o własnym pierwszym spotkaniu z poetą. Wyciągnął z niej jednak raczej nieoczekiwane wnioski:

Czytając ponownie Leśmiana, wracałem myślą do swoich pierwszych spotkań z poezją w ogóle. Były to najprostsze z możliwych sytuacje: kilka wierszy, żadnych informacji o autorze, naiwne próby przypasowania poetyckich zdań do własnego życia, równie naiwne zdziwienie tą bądź tamtą metaforą. Być może musimy ponownie nauczyć się takiej lektury? Kto wie, czy wiersze Leśmiana nie byłyby dobrym punktem wyjścia do takiej nauki? Wszak jest to poezja pierwszego, dziecięcego zdziwienia obrazem, słowem, dźwiękiem? ${ }^{23}$

Argument (znany nam w wysłowieniu Zadury), że o Leśmianie napisano już wszystko, zostaje tu najpierw przywołany aprobatywnie. Autorytetami Gutorowa (który sam prezentuje się jako czytelnik, poeta i krytyk, ale nie profesor filologii, choć przecież nim także jest) są Maria Podraza-Kwiatkowska i Janusz Sławiński. Aprobata nie jest jednak zupełna. Pisząc o powodach, dla których firmuje jeszcze jeden wybór poezji Leśmiana, Gutorow pyta retorycznie:

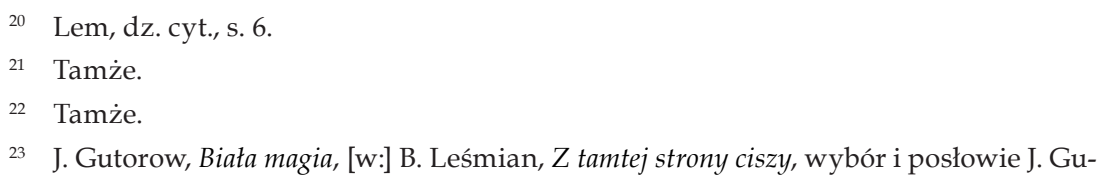


Czy dałbym radę wytłumaczyć, czemu wyprawiam się dobrze udeptanym szlakiem, zdając sobie sprawę, że niczego nowego na tej drodze już raczej nie odnajdę, że zapuszczam się w teren znakomicie opisany przez kartografów i przyrodników, tudzież nie najgorzej oswojony przez poszukiwaczy poetyckich przygód?24

Odpowiedź brzmi wpierw negatywnie („,nie potrafiłbym odpowiedzieć w satysfakcjonujący sposób"), ale następnie przeczenie zostaje uchylone: „O tej poezji można pisać bez końca. Każde spotkanie jest inne”25. Ostatecznie Gutorow stwierdza z całkowitą pewnością: „Czy da się czytać Leśmiana inaczej? Jak najbardziej!"26 - i od razu proponuje kilka wątków interpretacyjnych, ciekawych i rzeczywiście nowych, to znaczy będących jego własnym pomysłem lub przynajmniej takich, które nie zostały jeszcze wyeksploatowane przez leśmianologię. Do działu nowości należy też doliczyć propozycję „naiwnej” lektury Leśmiana, czyli czytania poza leśmianologiczną tradycją (jeśli się nie mylę, naiwne, nieuczone podejście jest zaledwie punktem wyjścia dla wzorca czytania proponowanego przez Gutorowa).

Dość nietypowo zatem Gutorow nie tylko pamięta dorobek poprzedników, lecz także go docenia - a mimo to jest w stanie powiedzieć coś nowego. Oczywiście również on pamięta wybiórczo; należałoby tu zresztą zaznaczyć, że nie wszystkie przejawy zapomnienia muszą być rozpatrywane jako element strategii retorycznej: leśmianologiczna bibliografia osiągnęła dziś takie rozmiary, że objęcie jej pamięcią, nie mówiąc już o głębszym przyswojeniu, zaczyna właśnie przekraczać granice możliwości (czego boleśnie doświadcza pisząca te słowa), a z pewnością je przekroczy, jeśli utrzyma się „lawinowe” tempo przyrostu prac o Leśmianie. Można by sądzić, że autentyczna czy udawana amnezja pozwoli leśmianologom uwolnić się od interpretacyjnych stereotypów i obiegowych prawd o poecie, jest to jednak przypuszczenie na ogół mylne. Tekst Gutorowa, odważnie wytyczający nowe ścieżki, wyrasta w tym aspekcie ponad krytycznoliteracką średnią. Bardziej typowe są wypowiedzi, w których nowość ujęcia ma charakter głównie językowy - polega na odświeżeniu słownika. Przykładem takiej uwspółcześniającej translacji może być szkic Grzegorza Czerwińskiego: mocno osadzony w tradycji leśmianologicznej topos „poezji przyrody” - w wariancie rozwiniętym przez Trznadla („mit regresu”) i Michała Głowińskiego („poeta jako człowiek pierwotny”) zyskał nową szatę leksykalną, stając się "filozofią ekologiczną" ${ }^{27}$ Leśmiana. Oczywiście nie jest to zwykła substytucja; jak to zazwyczaj z przekładem bywa, powstaje pewna nadwyżka sensu, a znów inne znaczenia zostają odsunięte na bok czy nawet zatarte.

24 Tamże, s. 70.

25 Tamże, s. 78.

26 Tamże, s. 75.

27 G. Czerwiński, Przyroda sama w sobie a dramat "Topielca", czyli o dylematach "filozofii ekologicznej” Bolesława Leśmiana, „Dzikie Życie” 2006, nr 2. 
Zmiany na poziomie słownikowym nie są więc obojętne i dlatego warto je odnotować. Jako przykład podam zaznaczającą się w wypowiedziach dotyczących motywów erotycznych u Leśmiana skłonność do zastępowania - będących wcześniej w powszechnym użyciu - formuł peryfrastycznych i eufemizmów jednoznacznymi, ale przez to dość dosadnymi, terminami fachowymi. Tam więc, gdzie dawniej mowa była o mgle jako pseudonimie "miłosnego spełnienia” czy o „autoerotyzmie”, albo inaczej: „związanej z niebytem erotyce czystej wyobraźni" (Sandauer) - teraz używa się po prostu słów „orgazm" i „masturbacja”" (pierwszy przykład pochodzi z artykułu naukowego Piotra Szweda, drugi - z felietonu Piotra Piętaka zamieszczonego na blogu internetowym ${ }^{28}$ ). Jest to, jak sądzę, coś więcej niż tylko zmiana stylistyczna - jest to przesunięcie interpretacyjne.

Przez cały okres obecnie rozgrywającego się „powrotu” leśmianologia wchodziła w kontakt z nieznanymi sobie wcześniej - na ogół poststrukturalistycznymi - językami teoretycznymi. Skutkowało to nie tylko wprowadzeniem nowych kategorii opisowych, ale też poszerzeniem indeksu osobowego autorytetów. Marcin Orliński powołał się np. na Richarda Rorty'ego, by opatrzyć Leśmiana etykietą „ironistki” (termin z książki Przygodność, ironia, solidarność) i by scharakteryzować poetę następująco:

Ironistka, w przeciwieństwie do metafizyka, nie wierzy, że można zbliżać się do jakiejś ostatecznej „prawdy” na gruncie jednego słownika finalnego, ani że świat posiada jakąś „,naturę", a rzeczy - „istotę"29.

Krytyk odwołał się ponadto do tekstu Narodziny filozofii postmodernistycznej z ducha sztuki modernistycznej Wolfganga Welscha oraz cytował (z drugiej ręki) słynną frazę z Kondycji ponowoczesnej: „Z postawą Leśmiana koresponduje, jak sądzę, sformułowanie, za pomocą którego Jean-François Lyotard opisywał postawę postmodernistyczną: «podejrzliwość wobec metanarracji»"30. Efekt autorytetu, czyli wzmocnienie argumentacji krytyka, jest tylko ubocznym skutkiem podobnych zestawień - leśmianologowi chodzi przede wszystkim o ujęcie przedmiotu w takie obramowanie z nazwisk i cytatów, które wyeksponuje jego pożądane właściwości. Rama nie musi być współczesna (Orliński cytował też Nietzschego), o ile przywoływane autorytety mieszczą się w obszarze dzisiejszej tradycji pozytywnej. Celem ostatecznym jest bowiem wykazanie, że twórczość Leśmiana pozostaje aktualna (co równa się wysokiej ocenie).

To, że twórczość ta łatwo poddaje się uwspółcześniającym ujęciom, że jest - jak pisała Anna Sobieska - „elastyczna”, również świadczy na jej korzyść. Sobieska wprawdzie zauważyła, że podatność na nowe interpretacje może

28 P. Szwed, Z księgi romantycznych przeczuć. Motyw ",widzacej natury” w poezji Bolestawa Leśmiana, [w:] Leśmian nowoczesny i ponowoczesny..., s. 88; P. Piętak, Leśmian - patron Europy, www. prawica.net, 14 listopada 2016 (dostęp: 4.11.2017).

29 M. Orliński, Ironia i perwersja w poezji Bolesława Leśmiana, „Kresy” 2007, nr 3, s. 218.

30 Tamże. 
być nie tyle właściwością samej poezji, co wynikać z rozpowszechniającej się dziś „ppolifonicznej” koncepcji dzieła poetyckiego, zgodnie z którą dzieło

[...] z lubością zezwala, by odkrywano [...] poszczególne warstwy, poziomy i penetrowano poukrywane mniej lub bardziej głęboko zakamarki, dające możliwość odmiennych od tych zazwyczaj spodziewanych sposobów artykulacji ${ }^{31}$

- niemniej badaczka przemilczała to, że przecież nie wszystkie dzieła próbuje się w ten sposób „penetrować”, więc chyba nie wszystkie mają dostatecznie wiele „warstw” i „zakamarków”. Wybór poezji Leśmiana nie jest aksjologicznie neutralny, podobnie jak nie jest neutralna zaangażowana w jej opis erotyczna metaforyka („,z lubością zezwala” etc.) oraz terminologia zapożyczona z psychoanalizy Jacques'a Lacana, z pism Daniela Sibony'ego, Rolanda Barthes'a, Jacques'a Derridy oraz z gender i queer studies (np. Judith Butler). Sieć terminów i metafor, w jaką Sobieska oplotła badany przedmiot, jest naprawdę gęsta:

Spróbuję zrekonstruować swego rodzaju scenariusz fantazmatyczny, jaki w pisany został w Leśmianowski poemat [Pan Błyszczyński], pewną logikę pożądania, jaka uwidacznia się w kreacyjnym spojrzeniu „błyszczydeł” tytułowego bohatera. Przedstawię więc ów poemat jako opowieść o uwodzeniu, o bezsilności uwodziciela, a przy okazji o matrofobii i kilku fantazmatycznych deformacjach, kliszach kobiecości, jakimi „napikowana” jest poezja twórcy perwersyjnych ballad o Pile, Gadzie, czy Pannie Annie - a więc mówić będę przede wszystkim o kobiecie jako traumie chaosu, o kobiecie jako suplemencie i dopełnieniu męskości, wreszcie o kobiecości jako szansie na transgresję; kobiecie jako Barthes'owskim punctum - łączniku z rzeczywistością pozajęzykową; miłosnej ranie zmieniającej i uwodzącej Oglądającego, pozwalającej mu przekroczyć granice słowa, przejść do świata, gdzie cisza i milczenie mówią ${ }^{32}$.

Stosowanie anachronicznych określeń sprawia wrażenie, że twórczość poety zostaje przemieszczona w przyszłość. I rzeczywiście, deklarowanym przez Sobieską celem analizy jest wykazanie prekursorstwa Leśmiana na gruncie historii idei (ujęcie badaczki stanowi więc wariant toposu „filozofii Leśmiana", ale wtórnie również toposu lokalizacji historycznoliterackiej: "gdzie umieścić Leśmiana?"). Sobieska ujawnia, że jej opis jest

[...] przede wszystkim próbą przedstawienia Leśmiana jako post-Leśmiana (określenie Marcina Orlińskiego), prekursora Lacanowskiego ujęcia

31 A. Sobieska, Pana Błyszczyńskiego fantazmowanie o kobiecości, czyli Leśmian o doświadczeniu queer, [w:] Leśmian nowoczesny i ponowoczesny..., s. 57.

32 Tamże, s. 58. 
kobiecości; prekursora perspektywy queer jako stanowiska postpłciowego, postawy dystansującej się do własnego znaczenia, własnej niestabilności, braku doświadczanego w sobie i Inności w świecie, postawy afirmującej RóżNIcę ${ }^{33}$.

Okazuje się więc, że jako prekursor Lacana i teorii queer (a chyba również dekonstrukcjonizmu) Leśmian wykracza poza modernizm - w kierunku postmodernizmu. Podobną tezę postawił przywołany przez Sobieską Orliński. Ogólnie można zauważyć, że dzisiejsi leśmianolodzy coraz odważniej lokalizują twórczość poety w ponowoczesności, a zatem w epoce, w której sami żyją. Zresztą już koncept Leśmiana-modernisty (w szerokim znaczeniu terminu „modernizm”), rozpropagowany przede wszystkim przez Ryszarda Nycza, niekoniecznie wykluczał poetę ze współczesności. Co prawda Nycz w przedmowie do Jezyka modernizmu zaznaczał, że modernizm jest formacją „W fazie zmierzchu, skostnienia, petryfikacji”"34 i w zasadzie już zamkniętą, z czego wynikało, że również modernistyczną twórczość Leśmiana oglądał badacz z zewnętrznej, postmodernistycznej perspektywy - jednak dystans był raczej deklaratywny. Inni leśmianolodzy dystans ten w ogóle unicestwiali, jak to czynił Markowski w podręcznikowej syntezie Polska literatura nowoczesna. Modernizm, a zwłaszcza jego nurt krytyczny (którego przedstawicielem miałby być Leśmian), nie jest oddzielony od „dziś” Markowskiego:

Leśmian, Schulz i Witkacy nie tylko stworzyli oryginalne myślowe i stylistyczne idiomy literackie [...], ale wynaleźli też języki, którymi może posługiwać się literatura nowoczesna, wolna od dziewiętnastowiecznych naleciałości, krytycznie opukująca myślową współczesność. Bohaterowie tej książki to polscy logoteci, wynalazcy, albo lepiej: ustawiacze języków [...], które do dziś zasługują na baczną uwage $e^{35}$.

Mimo wyeksponowania kwestii „języków”, Markowskiego interesuje raczej "filozoficzna” czy „kulturowa” interpretacja twórczości Leśmiana, stąd i w ocenie tej twórczości nie bierze pod uwagę jej ściśle literackich, językowo-stylistycznych wymiarów:

Leśmian, Schulz, Witkacy mówią nam coś ważnego o człowieku, o jego lękach, jego nadziejach, jego kłopotach ze samym sobą, o pomyłkach, ale mówią nam też o kłopotach, jakie człowiek nowoczesny ma z rozumieniem, interpretowaniem i przedstawianiem świata. $Z$ tego powodu są oni pisarzami nie tylko ważnymi dla przeszłości, ale także nieocenionymi dziś. [...] Ani Żeromski, ani Tuwim, ani Kaden-Bandrowski, ani Peiper nie

33 Tamże, s. 59

34 R. Nycz, Język modernizmu. Prolegomena historycznoliterackie, Wrocław 1997, s. 8.

35 M.P. Markowski, dz. cyt., s. 7. 
mogliby - tak uważam - zostać naszymi najbardziej współczesnymi, gdy chodzi o sprawy jednostki i jej relacji ze światem ${ }^{36}$.

Z diagnozą tą zapewne zgodziłaby się Magdalena Rabizo-Birek, chociaż zauważyła ona, że „Leśmian nie pisze o świecie, w którym żyjemy, który stanowi paradygmat nowoczesności" ${ }^{\prime 37}$. Mimo to Leśmian jest poetą nowoczesnym, i to w wielu wymiarach - według autorki „da się tego poetę postawić blisko poszukiwań np. Hermana Hessego i widzieć w nim prekursora współczesnej ekologii, New Age, alterglobalizmu, kreującego holistyczną wizję bytu jako łańcucha wszelkich istnień", a także „pełnego metafizycznego niepokoju agnostyka" ${ }^{\prime 38}$. Dlatego też Rabizo-Birek skłonna była uznać, że Leśmian - obok Różewicza - jest tym twórcą, który ma największy wpływ na polską poezję:

Wydaje mi się, że dziś aktualne, twórcze, dyskutowane, podejmowane i kontynuowane są dwie skrajne drogi w poezji, dwa projekty poetyckie wymierzone w Nic, które jest w nas i nas otacza. Jest to poezja Leśmiana i poezja Różewicza ${ }^{39}$.

Topika lokalizacyjna (w dwóch wariantach: postmodernistycznym i modernistycznym) stanowi ośrodkowy punkt leśmianologii w okresie obecnego „powrotu”. Umieszczenie twórczości Leśmiana w modernizmie lub nawet uznanie jej za prekursorską względem postmodernizmu jest tym, co odróżnia nowych leśmianologów (zmiana pokoleniowa też jest tu widoczna) od ich poprzedników.

Inna, choć już jednak nie tak ważna cecha wspólna to ponowne podjęcie zagadnienia stosunku Leśmiana (i jego poezji) do spraw narodowych, w tym toposu żydowskości/polskości. W drugiej połowie XX wieku topos ten funkcjonował na dwa sposoby: po pierwsze, przywoływany był w wyobcowującym cudzysłowie $\mathrm{w}$ ramach rytualnej narracji o odrzuceniu poety przez współczesnych; po wtóre, wykorzystywany był negatyw argumentów antysemickich, tzn. leśmianolodzy gromadzili dowody na „,rodzimość”, ,polskość", „słowiańskość" Leśmiana, a żydowskość marginalizowali (fundatorem tej linii był Sandauer). W kwestii związków poety z kulturą żydowską funkcjonowała swoista blokada poznawcza. Anna Czabanowska-Wróbel, która jako pierwsza tę blokadę przełamała, publikując w 2003 roku w „Pamiętniku Literackim" rewelatorski i bardzo przekonujący artykuł o mistyce żydowskiej w twórczości Leśmiana, wyjaśniła przyczyny oporu swoich poprzedników właśnie pamięcią o wystąpieniach krytyków nacjonalistycznych:

\footnotetext{
36 Tamże, s. 8-9.

37 M. Rabizo-Birek, Leśmian - tradycyjny czy nowoczesny?, „Fraza” 2007, nr 2, s. 290.

38 Tamże, s. 291.

39 Tamże, s. 290.
} 
Można podejrzewać, że do słabego, jak dotąd, oświetlenia wagi tradycji żydowskiej u Leśmiana przyczyniły się echa ataków antysemickiej publicystyki okresu międzywojennego [...] i pojawiające się w tego rodzaju tekstach próby naznaczania specyficznie „żydowskiego" sposobu uprawiania literatury ${ }^{40}$.

Po roku 2003 problem relacji Leśmiana z tradycją żydowską podjęła praska polonistka Michala Benešová ${ }^{41}$; temat wszedł też do dyskursu krytycznoliterackiego, np. Gutorow, niewątpliwie korzystając z ustaleń Czabanowskiej-Wróbel, pisał, że u Leśmiana „odnajdziemy ślady fascynacji pismami kabalistycznymi" ${ }^{\prime 2}$. Ten sam krytyk - już zupełnie samodzielnie - zwrócił też uwagę na inne przeoczone dotąd zagadnienie, kiedy zatrzymał się nad „niespodziewanym kresowym zaśpiewem ${ }^{\prime \prime 3} \mathrm{w}$ końcowym fragmencie dziewiątej części poematu Zielona godzina. Wpływ języków wschodniosłowiańskich na polszczyznę Leśmiana to problem, który powinno podjąć akademickie literaturoznawstwo.

Inną wersję toposu żydowskości/polskości prezentują publikacje współczesnych krytyków o orientacji narodowej. Pierwszy z tych tekstów to dość głośny w swoim czasie Rebus Leśmiana Krzysztofa Masłonia, opublikowany W weekendowym magazynie „Rzeczpospolitej” (2010). Krytyk posłużył się toposem w sposób nie do końca jawny. Przytoczył więc najpierw obszerne cytaty z przedwojennych krytyków nacjonalistycznych i opatrzył je komentarzem: „Dość to wszystko obrzydliwe" ${ }^{\text {.44 }}$ Kiedy jednak relacjonował spór Stanisława Pieńkowskiego z Antonim Langem, dorzucił uwagę: „Obiektywizm Langego był jednak wątpliwy; ten tłumacz Baudelaire’a był kuzynem Leśmiana"45; w innym zaś miejscu stwierdził, że „zastrzeżenia krytyków do Leśmianowej polszczyzny wykraczają poza antysemickie ramy"46, nie podał jednak ani jednego przykładu takich obiekcji, który nie byłby sformułowany w kontekście wypowiedzi antysemickiej.

Nic więc dziwnego, że inni autorzy w wypowiedzi samego Masłonia doszukiwali się zakamuflowanej postawy antyżydowskiej. Paweł Rams zinterpretował ją jako „paradygmatyczny” przykład „odżywania we współczesnym dyskursie" ${ }^{\prime \prime 7}$ języka i argumentacji skrajnych nacjonalistów. Rams zwrócił uwagę, że Masłoń dość zręcznie ukrywa antysemickie nastawienie, starając się nie przekroczyć obowiązujących norm poprawności politycznej.

40 A. Czabanowska-Wróbel, "Kto cię odmłodzi, żywocie wieczny?”: mistyka żydowska w poezji Bolesława Leśmiana, „Pamiętnik Literacki” 2003, z. 3, s. 86.

41 M. Benešová, Ve světle kabaly. Židovská mystika v polské literatuře meziválečného období (Aleksander Wat, Bruno Schulz, Bolesław Leśmian), Praha 2017.

42 J. Gutorow, dz. cyt., s. 72.

43 Tamże, s. 82.

44 K. Masłoń, Rebus Leśmiana, „Plus Minus” 2010, 31 lipca - 1 sierpnia, s. 11.

45 Tamże.

46 Tamże.

47 P. Rams, Wiek z Leśmianem, „Pamiętnik Literacki” 2013, z. 1, s. 223. 
Aluzje Masłonia wychwycił też Piotr Śliwiński. W felietonie w „Tygodniku Powszechnym" ironizował:

Masłoń dzieli pogląd o słabościach Leśmianowego wysłowienia, lecz uzasadnia go - oczywiście - inaczej. Leśmian nie zawsze potrafił dobrze pisać, ponieważ - nie potrafił. Antysemityzm i antymodernizm, żadnego powinowactwa, oczywiście.

Skąd więc mój niesmak? ${ }^{48}$

Tego rodzaju podejrzeń nie budzi szkic Bronisława Wildsteina Narodowość rozumiana jako język, argumentacja nakierowana jest $\mathrm{w}$ nim bowiem na wykazanie polskości Leśmiana. Według publicysty „Do Rzeczy” „polska afiliacja” Leśmiana "nie musiała być oczywista” - była więc sprawą świadomego wyboru, przede wszystkim wyboru języka, a właściwie "poezji pisanej $w$ języku konkretnego narodu"t49. W tym kontekście cytaty z przedwojennych krytyków nacjonalistycznych (niektóre z nich te same co u Masłonia) nabierają jednoznacznie negatywnego zabarwienia i autor nie próbuje ich cieniować, odróżniając to, co „dość obrzydliwe”, od tego, co brzmi rozsądnie. W kwestii literackiej rangi Leśmiana Wildstein również nie zgłasza zastrzeżeń: jest to dla niego „wielki i osobny talent” oraz „jeden z bardziej oryginalnych i twórczych artystów polskiego języka"50. Wypowiedź Wildsteina stanowi próbę uzgodnienia wartości narodowych z uznaniem dla pisarza pochodzenia żydowskiego. Rozwiązanie, oparte na retorycznym rozszczepieniu na "być Polakiem" i "stać się Polakiem”, było już wcześniej przyjmowane przez leśmianologów - po raz pierwszy zastosował je natomiast krytyk zorientowany narodowo. Widać tu zresztą pewną obawę, że argument odwołujący się do wyboru języka może okazać się niewystarczający dla wykazania polskości Leśmiana: uprzedzając ten zarzut, Wildstein przypomniał, że poeta "był nawet zatrzymany przez policję carską za patriotyczną aktywność"51 (ten heroiczny motyw jest obecny w niektórych ujęciach biograficznych, np. w książkach Piotra Łopuszańskiego).

Do takich asekuracji nie musiał się uciekać Rymkiewicz, który posłużył się podobnym schematem argumentacyjnym, lecz pominął dowodzenie, pokazując tym samym, że jest ono zbędne - polskość Leśmiana jest niekwestionowanym faktem. W liście otwartym Do redaktorów "Gazety Wyborczej" na zadane mi publicznie pytanie, jak naprawdę nazywat się mój ojciec odnoszący się do Leśmiana passus brzmi po prostu: „Bolesław Leśmian, z ojca Lesman, największy poeta polski XX wieku, pochodził z rodziny żydowskiej. Był

48 P. Śliwiński, Poeta, wieczny Żyd, http://www.tygodnikpowszechny.pl/poeta-wieczny-zyd-142908, 18.08.2010 (dostęp: 3.11.2017).

49 B. Wildstein, Narodowość rozumiana jako język, „Do Rzeczy” 2014, nr 51-52, s. 66.

50 Tamże, s. 66, 68.

51 Tamże, s. 66. 
dobrym Polakiem"52 (podobną konstrukcję mają pozostałe elementy tego przypominającego litanię wyliczenia, każdy poświęcony innemu polskiemu pisarzowi). Wypowiedzi Rymkiewicza i Wildsteina dowodzą, że polska krytyka zorientowana narodowo nie musi być automatycznie antysemicka.

Topos polskości/żydowskości Leśmiana pojawił się ponadto w publicystyce dotyczącej kwestii niedoszłego Roku Leśmiana (przypomnę, że chodziło o odrzucenie przez Senat Rzeczypospolitej Polskiej propozycji, by z racji dwóch okrągłych rocznic poeta został ogłoszony patronem roku 2017). W „Polityce” Justyna Sobolewska dociekała: „Dlaczego jeden z największych poetów polskich okazał się nieodpowiedni? Co przeszkadzało - żydowskie pochodzenie? To, że pisał erotyki?”53. Bartosz Palocha w „Krytyce Politycznej” zgadywał dość podobnie:

Może poza żydowskim pochodzeniem największą jego zbrodnią jest to, że nie chciał się wpisać w starą polską tradycję dwulicowości. [...] Nie przyjmował też świątobliwej miny. [...]

Bolek, rozpustny Żyd, zanurzający się w mitycznej Słowiańszczyźnie, to już prawdziwe multi-kulti ${ }^{54}$.

W „Gazecie Wyborczej” Jarosław Mikołajewski, rozważając przyczyny tego odrzucenia, stwierdził natomiast sarkastycznie: „Ale chyba nie chodzi o pochodzenie. Przecież brak uprzedzeń senatorowie udowodnili akceptacją Madonny o mojżeszowym rodowodzie"55 (krytyk zrobił tu aluzję do faktu, że zdominowany przez prawicowych polityków Senat opowiedział się za innymi kandydatami na patronów, w tym za Matką Boską Częstochowską). Artykuł Mikołajewskiego pod wieloma względami przypomina zwykły portret krytyczny (w tym wypadku z dominantą biograficzną), ale krytycznoliterackie funkcje poznawczo-oceniająca i operacyjna podporządkowane są tezie politycznej, wyrażonej w puencie tekstu: „Senatorowie PiS odrzucili język, w którym wszyscy czujemy się jak w samym sercu najbardziej istotnego istnienia" ${ }^{\prime \prime 6}$. Również zastosowane przez Mikołajewskiego argumenty z autorytetu ostatecznie odnoszą się do polityki, nie do poezji: „I zastanawia, dlaczego przed głosowaniem prawica nie poszła po rozum do mędrców, których uważa za guru" - pisał publicysta "Gazety Wyborczej”, wskazując

52 J.M. Rymkiewicz, Do redaktorów ",Gazety Wyborczej” w odpowiedzi na zadane mi publicznie pytanie, jak naprawdę nazywat się mój ojciec, https://wpolityce.pl/m/polityka/116008-do-redaktorow-gazety...-mi-publicznie-pytanie-jak-naprawde-nazywal-sie-moj-ojciec (dostęp: 4.11.2017).

53 J. Sobolewska, Nie dajmy znikną́ Leśmianowi, „Polityka” 2017, nr 1, s. 130.

54 B. Palocha, Sami uczcimy Rok Leśmianowski, http://krytykapolityczna.pl/kultura/ czytaj-dalej/sami-uczcimy-rok-leśmianowski/, 22 stycznia 2017 (dostęp: 9.02.2018).

55 J. Mikołajewski, Leśmian. Bolesław Wielki, król bez korony, http://wyborcza. pl/7,75517,20967001,lesmian-boleslaw-wielki-krol-bez-korony.html, 12 listopada 2016 (dostęp: 31.10.2017).

56 Tamże. 
na Trznadla i Rymkiewicza jako autorów „wspaniałych książek o Leśmianie $^{\prime \prime 57}$. Słowem, tekst Mikołajewskiego, podobnie jak inne wypowiedzi związane z niedoszłym Rokiem Leśmiana, realizuje funkcje krytycznoliterackie w sposób pretekstowy i ciąży ku publicystyce politycznej. To upolitycznienie Leśmiana stanowi kolejne novum leśmianologii, choć zauważyć też należy, że sprawa „roku, którego nie było” (by sparafrazować tytuł podsumowującego, bardzo zresztą wyważonego, artykułu Marcina Napiórkowskiego w „Wię$\mathrm{zi}^{\prime \prime 58}$ ) idealnie wpisuje się w legendę „bolesnej sławy” Leśmiana i najprawdopodobniej w tej legendzie trwale się ulokuje.

\section{B I B L I O G R A F I A}

Boniecki E., Archaiczny świat Bolesława Leśmiana. Studium historycznoliterackie, Gdańsk 2008.

Cockiewicz W., Metaforyka Leśmiana (analiza lingwistyczna), Kraków 2011.

Czabanowska-Wróbel A., Dyskrecja, „Teksty Drugie” 2002, nr 1/2.

Czabanowska-Wróbel A., "Kto cię odmłodzi, żywocie wieczny?”. Mistyka żydowska w poezji Bolestawa Leśmiana, „Pamiętnik Literacki” 2003, z. 3.

Czaplejewicz E., Stowo wstępne, [w:] Poetyki Leśmiana. Leśmian i inni, pod red. E. Czaplejewicza i W. Sadowskiego, Warszawa 2002.

Czerwiński G., Przyroda sama w sobie a dramat "Topielca", czyli o dylematach "filozofii ekologicznej” Bolesława Leśmiana, „Dzikie Życie” 2006, nr 2.

Dobrowolska K., Budowniczy złotych mostów. Leśmian i retoryczna krytyka metafor, Warszawa 2014.

Gorczyńska M., Miejsca Leśmiana. Topika recepcji krytycznoliterackiej, Kraków 2011.

Grodzki B., Leśmianowska baśń nowoczesna. O "Przygodach Sindbada Żeglarza" Bolesława Leśmiana, Lublin 2012.

Gutorow J., Biała magia, [w:] B. Leśmian, Z tamtej strony ciszy, wybór i posłowie J. Gutorow, Wrocław 2012.

Kaźmierczak M., Przekład w kręgu intertekstualności. Na materiale tłumaczeń Bolesława Leśmiana, Lublin 2012.

Leśmian B., „Lecz nie było już świata...". Miłość i śmierć. Wiersze, całość ułożył, fotografie wykonał i słowem wstępnym opatrzył A. Nowakowski, Kraków 2017.

Leśmian, Leśmian.... Wspomnienia o Bolestawie Leśmianie, zebrane przez A.W. Kulika, Gdańsk 2008.

Leśmian nowoczesny i ponowoczesny, pod red. B. Grodzkiego i D. Trześniowskiego, „Radomskie Monografie Filologiczne” 2012, nr 1.

Łopuszański P., Leśmian, Wrocław 2000.

Łopuszański P., Bolesław Leśmian. Marzyciel nad przepaścia, Warszawa 2006.

Łopuszański P., Zofia i Bolestaw Leśmianowie, Kraków 2005.

57 Tamże.

58 M. Napiórkowski, Rok, którego nie ma, „Więź” 2017, nr 2. 
Masłoń K., Rebus Leśmiana, „Plus Minus” 2010, 31 lipca - 1 sierpnia.

Markowski M.P., Polska literatura nowoczesna. Leśmian, Schulz, Witkacy, Kraków 2007.

Mikołajewski J., Leśmian. Bolestaw Wielki, król bez korony, http://wyborcza. pl/7,75517,20967001,lesmian-boleslaw-wielki-krol-bez-korony.html, 12 listopada 2016 (dostęp: 31.10.2017).

Nalewajk-Turecka Ż., Leśmian międzynarodowy - relacje kontekstowe. Studia komparatystyczne, Kraków 2015.

Napiórkowski M., Rok, którego nie ma, „Więź” 2017, nr 2.

Nawrocki M., Wariacje istnieniowe. O ontologii poetyckiej Bolesława Leśmiana, Tarnów 2009.

Orliński M., Ironia i perwersja w poezji Bolesława Leśmiana, „Kresy” 2007, nr 3.

Pachocki D., Zagadnienia i zagadki edytorskie w rękopisach Bolestawa Leśmiana, „Tematy i Konteksty" 2012, nr 2.

Palocha B., Sami uczcimy Rok Leśmianowski, http://krytykapolityczna.pl/kultura/czytaj-dalej/sami-uczcimy-rok-leśmianowski/, 22 stycznia 2017 (dostęp: 9.02.2018).

Piętak P., Leśmian - patron Europy, www.prawica.net, 14 listopada 2016 (dostęp: 4.11.2017).

Poezje Bolestawa Leśmiana. Interpretacje, pod red. B. Stelmaszczyk i T. Cieślaka, Kraków 2000.

Polaszek P., Poezja Bolestawa Leśmiana w refleksji naukowej 2011-2015, [w:] Młoda Polska w najnowszych badaniach, pod red. E. Jakiela i T. Linknera, Gdańsk 2016.

Polaszek P., Recepcja poezji Bolestawa Leśmiana w pierwszym dziesięcioleciu XXI wieku. Rekonesans, [w:] Literatura na progu XXI wieku, pod red. J. Chłosty-Zielonki i Z. Chojnowskiego, Olsztyn 2014.

Rabizo-Birek M., Leśmian - tradycyjny czy nowoczesny?, „Fraza” 2007, nr 2.

Rams P., Wiek z Leśmianem, „Pamiętnik Literacki” 2013, z. 1.

Rymkiewicz J.M., Leśmian. Encyklopedia, Warszawa 2001.

Sobieska A., Pana Błyszczyńskiego fantazmowanie o kobiecości, czyli Leśmian o doświadczeniu queer, [w:] Leśmian nowoczesny i ponowoczesny, pod red. B. Grodzkiego i D. Trześniowskiego, „Radomskie Monografie Filologiczne” 2012, nr 1.

Sobieska A., Twórczość Bolesława Leśmiana w kręgu filozoficznej myśli symbolizmu rosyjskiego, Kraków 2005.

Sobolewska J., Nie dajmy zniknać Leśmianowi, „Polityka” 2017, nr 1.

Stelmaszczyk B., Istnieć w dwoistym świecie.... Model człowieka i obrazy Boga w poezji Bolestawa Leśmiana, Łódź 2009.

Stulecie „Sadu rozstajnego", pod red. U.M. Pilch i M. Stali, Kraków 2014.

Szwed P., Oddaleniec: poezja Bolestawa Leśmiana wobec romantyzmu polskiego, Katowice 2014.

Szwed P., Z księgi romantycznych przeczuć. Motyw "widzacej natury” w poezji Bolesława Leśmiana, [w:] Leśmian nowoczesny i ponowoczesny, pod red. B. Grodzkiego i D. Trześniowskiego, „Radomskie Monografie Filologiczne” 2012, nr 1.

Śliwiński P., Poeta, wieczny Żyd, http://www.tygodnikpowszechny.pl/poeta-wieczny-zyd-142908, 18 sierpnia 2010 (dostęp: 3.11.2017).

Twórczość Bolesława Leśmiana. Studia i szkice, pod red. T. Cieślaka i B. Stelmaszczyk, Kraków 2000. 
Wawryk J., Wokół Leśmianowskich baśni dla dzieci, Wrocław 2013.

"Wiecznie siebie nowego głodnym, jak żuraw z szyją w przyszłość wyciagnięta" - Bolestaw

Leśmian 1877-1937, red. A. Kluba, Warszawa 2017.

Wildstein B., Narodowość rozumiana jako język, „Do Rzeczy” 2014, nr 51-52.

Zadura B., „Trudno dać imię temu, co w dalekość ptynie...", [w:] B. Leśmian, Poezje, wybrał i wstępem opatrzył B. Zadura, Lublin 1982.

Zięba J., Bolestawa Leśmiana światopogląd nowoczesny. O eseistyce poety, Kraków 2000.

\section{STRESZCZENIE}

Artykuł stanowiący postscriptum do książki Miejsca Leśmiana. Topika recepcji krytycznoliterackiej (2011) szkicuje historię krytycznoliterackiego odbioru twórczości Bolesława Leśmiana od pierwszych lat XXI wieku do jubileuszowego roku 2017. Przyspieszenie recepcji, wyraźnie zaznaczające się już na początku lat dziewięćdziesiątych XX wieku, w omawianym okresie nie tylko utrzymało się, ale wręcz wzmogło. Krytycy coraz śmielej mówią też o prekursorstwie Leśmiana względem dwudziestowiecznego modernizmu i postmodernizmu; "(post)modernizacjom” Leśmiana towarzyszą z kolei zmiany na poziomie językowym (choć część z nich ma charakter raczej powierzchowny). Mimo akcentowanej przez krytyków nieciągłości, trwający od ponad dwóch dekad „powrót do Leśmiana” jest w znacznej mierze powrotem do ujęć oraz wątków wcześniejszej recepcji. Zdarzają się jednak znaczące przesunięcia, np. w użyciach toposu żydowskości/polskości Leśmiana. Do zjawisk zupełnie nowych należy natomiast upolitycznienie dyskursu o poecie.

\section{Słowa kluczowe}

Bolesław Leśmian, recepcja, krytyka literacka, topos krytycznoliteracki

\section{S UM M A RY}

\section{The place of Leśmian today (on contemporary literary criticism reception)}

The paper, being a postscript to the book Miejsca Leśmiana. Topika recepcji krytycznoliterackiej (Leśmian's places. The topos of critical reception) (2011), outlines the history of literary criticism reception of Bolesław Leśmian's output from the first years of the 21st century to the jubilee year 2017. Not only did the accelerated reception visible already in the early 1990s continue to gain momentum but it even got stronger in the analyzed period. Critics are bolder and bolder in speaking of Leśmian as a precursor of the 20th century modernism and postmodernism; "(post) modernizations" of Leśmian are accompanied, in turn, by changes on the level of language (even though some of them are rather superficial). Despite the discontinuity highlighted by critics, this "return to Leśmian", which has lasted for over two 
decades, is to a large extent a come-back to approaches and threads of earlier reception. There are, however, significant shifts, e.g. in the uses of the topos of Leśmian's Jewish/Polish identity. Totally new phenomena, in contrast, include politicization of the discourse about the poet.

\section{Keywords}

Bolesław Leśmian, reception, literary criticism, literary critical topos 